\title{
Groundwater contamination in caves: four case studies in Spain
}

\author{
Monserrat Jiménez-Sánchez ${ }^{1}$, Heather Stoll ${ }^{1}$, Iñaki Vadillo², Manolo López-Chicano ${ }^{3}$, \\ María Domínguez-Cuesta ${ }^{1}$, Wenceslao Martín-Rosales ${ }^{3}$ and Mónica Meléndez-Asensio ${ }^{1,4}$
}

\begin{abstract}
:
Jiménez-Sánchez M., Stoll H., Vadillo I., López-Chicano M., Domínguez-Cuesta M., Martín-Rosales W. and Meléndez-Asensio M. 2008. Groundwater contamination in caves: four case studies in Spain. International Journal of Speleology, 37 (1), 53-66. Bologna (Italy). ISSN 0392-6672.

Groundwater quality was monitored in four Spanish caves using concentrations of nitrate, potassium, phosphorus and in some cases total organic carbon. Three of the caves are located in NW Spain and contain prehistoric cave paintings and hence have special conservation interest. Of these, two are open show caves (Tito Bustillo and Pindal Caves), while the other one (Herrerías Cave) is not managed for tours and is partially closed off to public access. The fourth cave (Las Maravillas Cave) is located in SW Spain and is opened to the public because of its geological features and natural beauty. In this paper, we compare two sampling methodologies used in the four caves. In Pindal and Herrerias Cave high temporal resolution is achieved with a dripwater collector that collects discrete samples every 48 hours. In Tito Bustillo and Las Maravillas Caves a higher spatial resolution is achieved (16 sampling points in each one), but with a frequency of sampling ranging from 15 days to 6 months. Wastewater and livestock waste appear to be the principal sources of contamination to cave waters. Caves with concentrated livestock (stables) or urban and residential wastewater systems directly situated above the cave exhibit the highest level of contamination detected in elevated concentrations of nitrogen species and in some cases depressed oxygen availability in waters.
\end{abstract}

Keywords: cave, karst, water contamination, groundwater, dripwater.

Received 8 October 2007; Revised 21 December 2007; Accepted 26 December 2007

\section{INTRODUCTION}

Soil and vadose zone of aquifers act as protective covers to groundwater (Mudry et al., 2003), so specific studies of subsurface water flow and solute transport that could be contaminants in both environments are necessary. These studies are essential for a better understanding of the attenuation factors affecting the contaminants before their arrival to the underground resource. The methodology applied to the study of porous aquifers is different from that applied to carbonate (karstic) aquifers (Stephens, 1995; Selker et al., 1999). The reason for this difference is

1 Department of Geology, University of Oviedo, C/Arias de Velasco s/n, 33005. Oviedo(Spain).mjimenez@geol.uniovi.es, hstoll@geol.uniovi.es, mjdominguez@geol.uniovi.es

2 Department of Geology, Faculty of Sciences, University of Málaga, 29071. Málaga Vadillo@uma.es

3 Department of Geodynamic, Faculty of Sciences, University

of Granada. 18002 Granada (Spain).mlopezc@ugr.es,

wmartin@ugr.es

4 Spanish Geological Survey. C/Matemático Pedrayes, 25.

33005 Oviedo (Spain). m.melendez@igme.es based on (1) a higher heterogeneity of karst media, (2) field experiments (suction caps) and laboratory works (sorption-desorption experiments) that are not suitable for application to carbonate aquifers and (3) a thicker vadose zone in karst aquifers. For these three reasons, it is not possible to extrapolate the vadose zone methodologies of porous media to karstic environments. In addition, contamination processes of carbonate aquifers in the vadose zone behave in a different manner than in porous media (Worthington et al., 2000). Firstly, because some karstic elements at the land surface (dolines or swallow holes) favour the concentration of flow towards underground water resources; if a contamination episode on the exokarst occurs, contaminants will travel fast and propagate along the endokarst, leading to the degradation of subsurface water in karst conduit flows and dripwaters. This bypass of the soil and unsaturated zone makes the karst aquifers extremely vulnerable to groundwater contamination. Secondly, an irregular distribution of the contaminants will be produced as a consequence of the heterogeneity of the karst (Worthington et al., 2000; Vadillo et al., 2005). Finally, the hydrogeochemical reactions will depend 
on where the contaminant will be stored, because some conservative or low degradable contaminants in anoxic environments might be maintained in the matrix of the rock and released at a low but also at a constant rate towards secondary or tertiary porous parts of the rock.

Karst environments, allow access to deeper parts of the non-saturated zone through caves that might be considered natural laboratories for earth scientists, enabling the study of water flows and biochemical processes of solutes from ground surface to water table (Carrasco et al., 1995; Emblanch et al., 2003; Kaufmann, 2003; Musgrove and Banner, 2004). Therefore, caves are vulnerable recipients of contamination produced by activities on the land surface and serve as a window through which the karst aquifers, common resources for public water supply, can be monitored (Klimchouk and Gudzenko, 1996).

Most of the sources of contamination of karstic groundwater are waste dumping activities (pointsources) or agriculture and farming activities (areal sources). Possible contaminants from the latter activities include nutrients added as fertilizers (mainly sulphate, nitrogenous and phosphorous compounds and potassium), pesticides applied to crops, bulk parameters (Total Organic Content) and bacteria. Although heavy metals can come from natural sources, they can be found as contaminants in karst systems linked to acid mine drainage, urban and manufacturing use among other activities (Vesper, 2004). Light nonaqueous phase liquids (mainly BTEX) are also important contaminants with can be related to different human activities and their appearance in karst is often linked to human misuse, transportation accidents, leaking tanks or improper disposal (Loop, 2004).

In this paper, the methodology and results obtained in four Spanish caves, where detailed research has been carried out during the last years has been compared (Martín Rosales et al. 1995a, 1995b; Jiménez-Sánchez et al., 2002a, Liñán et al., 2004, Stoll et al., 2007). Three of the caves are located in NW Spain and prehistorical paintings are preserved and hence special conservation is needed. Of these, two are open for guided tours (Tito Bustillo and Pindal Caves), while the other one (Herrerias Cave) is not managed for tours and is partly closed off to public access. The fourth cave (Maravillas Cave) is located in SW Spain and is opened to the public because of its geological features and natural beauty. Two sampling approaches were compared; (1) in Pindal and Herrerias Cave high temporal resolution is achieved with a dripwater collector obtaining discrete samples every 48 hours whereas (2) in Tito Bustillo and Maravillas Caves, a higher spatial resolution is achieved (16 sampling points in each one), but with a frequency of sampling ranging from 15 days to 6 months. For the four cavities, concentrations of three potential indicators of contamination, nitrogen, phosphorus, and potassium, were measured. Additional indicators such as total organic carbon (TOC), dissolved oxygen, and biological oxygen demand were determined in some caves.

The aims of this work are (1) to show the methodology and results obtained in groundwater contamination in each case; (2) to establish the relationships between land use and hydrochemical impact on each cave and (3) to conclude advantages and disadvantages of each methodology for the required purpose.

\section{Setting}

\section{PINDAL CAVE}

Pindal Cave is located to the East of Asturias (NW Spain), 4${ }^{\circ} 30^{\prime} \mathrm{W}, 43^{\circ} 23^{\prime} \mathrm{N}$ (Figures 1 and 2). The cave, open since 1908 , is visited through guided tours 5 days a week year round. Previous geomorphological research in the area (Jiménez-Sánchez et al., 2002b, 2006) identified the karst recharge system and cave development. The Cave is $590 \mathrm{~m}$ long (314 $\mathrm{m}$ open to tourist use), trends E-W and $110^{\circ} \mathrm{N}$ (WNW-ESE) and opens $24 \mathrm{~m}$ above sea level (Obeso et al., 1996). The cave is developed in Carboniferous Barcaliente Limestone in the Ponga-Cuera Unit of the Cantabrian Zone (Marquinez, 1989). The cave orientation is mainly controlled by two sets of subvertical fractures trending $\mathrm{E}-\mathrm{W}$, elongated dolines and dry valleys. Two marine erosion terraces are prominent. The cave system is developed in the karstic massif of the Pindal Terrace (50-64 m). An upper marine terrace, the Pimiango terrace (125-170 m), is modelled on Ordovician quartz arenites. Fluviotorrential systems flow down the north flank of the Pimiango terrace and sink into the karstic Pindal terrace. The karst aquifer is recharged by this drainage off the Pindal Rasa and rainfall on the karst terrace itself. Sea cliffs expose evidence of a now collapsed lower phreatic-conduit system below Pindal Cave. A lower phreatic-conduit system is inferred to drain the karst aquifer during most of the year. During times of extended high precipitation, lower conduit systems appear to saturate and with the rising water table, water begins to flow in a channel in Pindal Cave. During 2004 the channel in the cave became active four times, all during spring months and when the cumulative precipitation over three days exceeded 37 $\mathrm{L} / \mathrm{m}^{2}$.

During wet months, typically October through May, a shallow $(<0.5 \mathrm{~m})$ pond of water develops at the base of the Pimiango terrace, likely recharged from rain and the fluvio-torrential system. The watershed feeding the karst system is rural. Land use on the Pimiango terrace includes livestock pasture and feeding operations, row crops, and hay meadow. The exokarst of the Pindal terrace contains pasture, stable and feeding areas. The village of Pimiango is on the upper Pimiango terrace and is also a potential source of water contaminants that can enter the karst through the fluvio-torrential systems. During the period of this study (2003-2006) a restaurant located in the exokarst over the cave was operative from July to September.

\section{Methodology}

We analyzed dripwater flow and chemistry of a drip located about $300 \mathrm{~m}$ from the cave entrance 


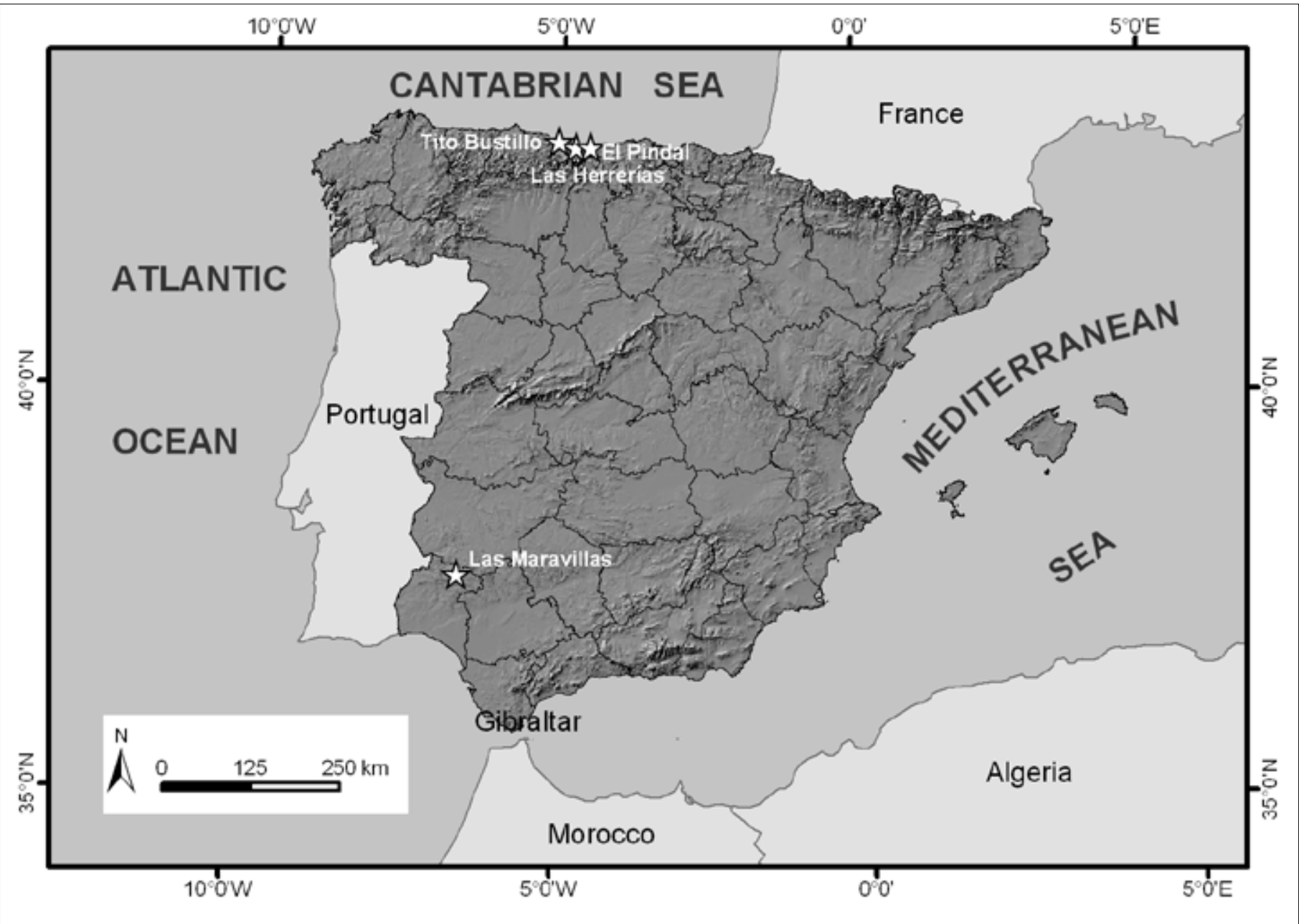

Fig. 1. Setting of the four caves in the context of the Iberian Peninsula
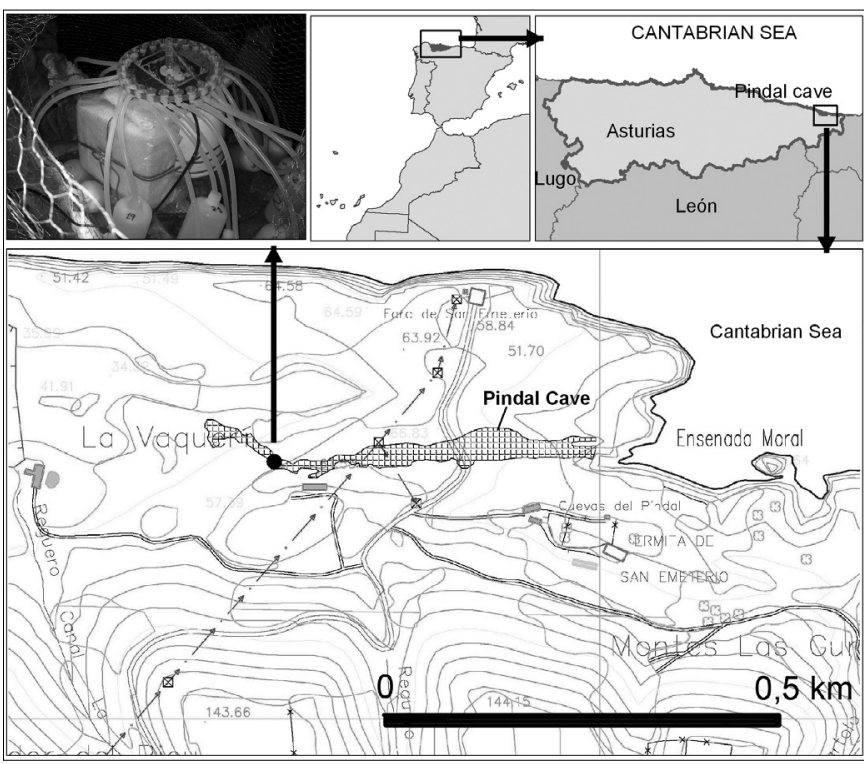

Fig. 2. Setting of Pindal Cave showing the location and a detail of the sample collector.

(Figure 2). From December 26, 2003 to November 18, 2004 and from December 2, 2005 to July 2, 2006 we deployed a battery-powered dripwater collector to collect dripwater during each 48 hour period in discrete $1.5 \mathrm{~L}$ bottles. The array contains 24 bottles and is deployed for 48 day intervals.

Upon collections, the volume of water was measured. Two aliquots were retained for geochemical analysis, one non-acidified for ion chromatography and one acidified to recover primary cation concentrations because dripwaters are supersaturated with respect to calcium carbonate in atmospheric environments and carbonate may precipitate in sample bottles. We measured the volume of water collected, returned 20 $\mathrm{mL}$ to the collection bottle, and split the remaining sample in two aliquots. To this $20 \mathrm{~mL}$ of sample in the collection bottle, $5 \mathrm{~mL}$ of tracepure $10 \% \mathrm{HCl}$ was added and the resulting solution swirled around the bottle to dissolve all precipitates. Half of this acidified solution $(12.5 \mathrm{~mL})$ was transferred from the collection bottle and added to one of the previously extracted aliquots (hence, referred to as the acidified fraction). The other half of the acid $(12.5 \mathrm{~mL})$ was discarded. We also collected samples of surface waters and cave-stream water on 2 March 2006, and samples of cave-channel water were collected on 26 April 2007.

Concentrations of $\mathrm{P}, \mathrm{K}$, and Na were measured on the acidified fraction via Inductively Coupled Plasma Emission Spectroscopy (ICP-ES) on a Thermo IRISICAP DUO. Concentrations of nitrate were measured on the non-acidified fraction via Ionic Chromatography (IC). For the 2003-2004 series, every other sample bottle was measured for IC so sample resolution is lower than for $\mathrm{P}$ and $\mathrm{K}$.

\section{Results and discussion}

Mean levels in cave dripwaters (Table 1) are well below EPA (United States Environmental Protection 
Agency) drinking water standards for all elements. Concentrations of nitrate, potassium, and phosphorus in cave dripwaters vary significantly over time (Figure 3).

Mean concentrations of $\mathrm{NO}_{3}^{-}$are higher in the 2005-2006 series than during comparable season in the 2003-2004 series. We highlight seven events in the 2003-2004 series when levels of both $\mathrm{K}$ and $\mathrm{NO}_{3}^{-}$double relative to what we characterize as baseline levels in December 2003-January 2004, and two pulses of higher $\mathrm{K}$ in the 2005-2006 series (Figure 3). Events 1-5 last about 1 week. Events 6 and 7 are distinctive due to their longer duration of 2 and 4 weeks, respectively, and because they are accompanied by elevated levels of $\mathrm{P}$ as well. Peaks in $\mathrm{K}$ are not correlated with changes in $\mathrm{Na}$ concentration, which varies little in drip waters, and thus cannot be attributed to sea salt aerosols. There is no consistent meteorological/hydrological situation common to all of the events of $\mathrm{K}$ and $\mathrm{NO}_{3}{ }^{-}$increase. Events 1, 3, and 4 occurred during low drip rates with negligible flow during the event or in the preceding week. Events 2 and 5 occurred within 2 days of moderate rainfall events. Events 6 and 7 began during rain events, and several rain events occurred through the duration of event 7. During the period of sample collection, several comparable rain events occurred without triggering increases in $\mathrm{K}, \mathrm{NO}_{3}^{-}$, or $\mathrm{P}$. This suggests that precipitation events are not the sole trigger for increased $\mathrm{K}, \mathrm{P}$, and $\mathrm{NO}_{3}{ }^{-}$concentrations in the dripwater, although precipitation events may interact with other changes in conditions in the drip source area. Very high $\mathrm{K}$ and $\mathrm{NO}_{3}^{-}$levels, but not unusually high $\mathrm{P}$ levels, were found in the ponded water at the base of the Pimiango terrace when sampled on 2 March 2006 (Table 1). Incursions of water from this pond, (or from water sharing a common source as the pond) into the aquifer feeding the dripwater network appear to be likely sources for the peaks in $\mathrm{NO}_{3}{ }^{-}$and $\mathrm{K}$ observed throughout the year. Events 6 and 7 , unique in their high $\mathrm{P}$ levels and magnitude of peaks in $\mathrm{K}$ and $\mathrm{NO}_{3}^{-}$, likely represent pulsed additions of these

\begin{tabular}{|c|c|c|c|c|c|c|c|c|c|}
\hline & \multicolumn{4}{|c|}{ Full series } & \multicolumn{5}{c|}{2 March 06 } \\
\hline & $\begin{array}{c}\text { Dripwater } \\
2003-2004\end{array}$ & $\begin{array}{c}\text { Dripwater } \\
2003-2004\end{array}$ & $\begin{array}{c}\text { Dripwater } \\
2005- \\
2006\end{array}$ & $\begin{array}{c}\text { Dripwater } \\
2005- \\
2006\end{array}$ & Dripwater & \multicolumn{3}{|c|}{ Surface waters } & Cave stream \\
\hline & mean & maximum & mean & maximum & & West & East stream & Pond \\
\hline $\mathrm{NO}_{3}^{-}$ & 1.07 & 5.14 & 2.7 & 5.1 & 5.1 & 13.31 & 4.59 & 1.64 \\
\hline $\mathrm{P}(\mathrm{mg} / \mathrm{L})$ & 0.93 & 4.54 & 0.46 & 0.82 & 0.7 & 2.04 & 1.74 & 0.325 \\
\hline $\mathrm{Na}^{+}(\mathrm{mg} / \mathrm{L})$ & 41.2 & 48.2 & 46.1 & 49.1 & 45.95 & 13.7 & 20.4 & 19.2 & 0.000 \\
\hline
\end{tabular}

Table 1. Mean and maximum values for $\mathrm{NO}_{3}^{-}, \mathrm{K}^{+}, \mathrm{P}$ and $\mathrm{Na}^{+}(\mathrm{mg} / \mathrm{L})$ in dripwaters, surface waters and cave stream in Pindal Cave.
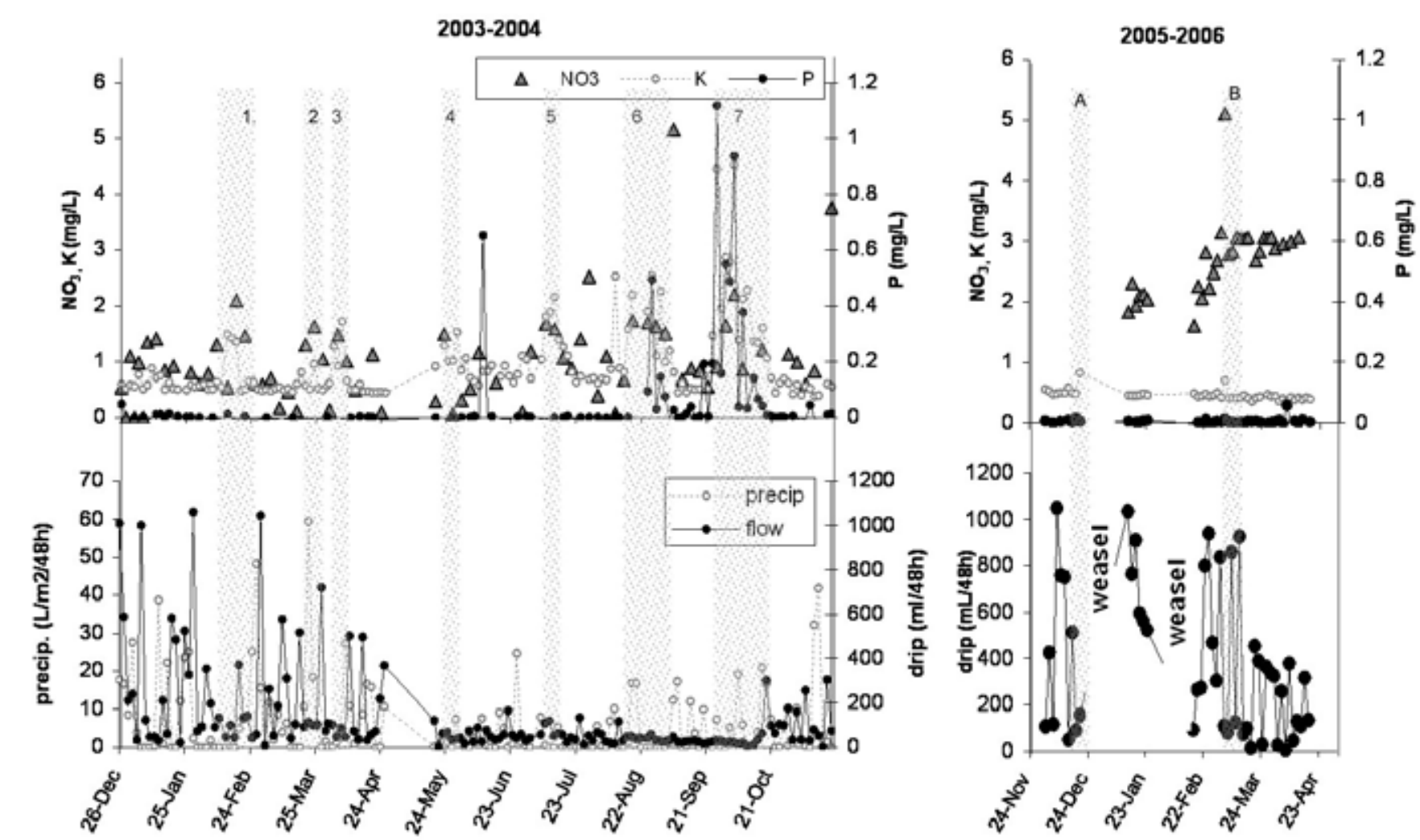

Fig. 3. Temporal evolution of hydrochemical parameters in Pindal Cave 
components to the watershed. While $\mathrm{P}$ and $\mathrm{NO}_{3}^{-}$can be very elevated in livestock or human waste, the concentrations of $\mathrm{K}$ found in the pond above the cave (53.72 mg/L K, Table 1) are not typical of livestock or animal waste and likely reflect accumulated fertilizer runoff. The fall dripwater events 6 and 7 likely reflect fertilization of areas on the Pimiango terrace with $\mathrm{N}$, P, and $\mathrm{K}$ following the harvest of hay and crops and prior to the seeding of winter pasture. Fertilizers were readily washed into the karst aquifer during the persistent rainfall over this period.

Throughout much of the year, fertilizer runoff accumulates in the pond with the exception of $\mathrm{P}$ which could be preferentially retained in autigenic soil minerals. Higher levels of $\mathrm{NO}_{3}^{-}$in winter-spring 2006 without change in $\mathrm{K}$ likely reflect increased significance of livestock waste in the watershed or less likely a change in ratio of fertilizers.

The water in the cave channel, sampled on 27 April 2007, exhibits the highest levels of nitrate, $14 \mathrm{mg} / \mathrm{L}$ of any water sampled in Pindal Cave. This water is also characterized by unusually high TOC (>8 mg/l). We interpret this channel as representative of karst conduit waters which likely receive a significant contribution from the village and agricultural activities on the upper Pimiango terrace as well as the small livestock operation directly on the epikarst. Comparably nitrate concentrations were found in the west stream draining the Pimiango Range on 2 March 2006 (13.31 mg/L, Table 1). Likely sources for the high nitrate and TOC are livestock waste and potentially wastewaters from the village.

\section{Setting}

\section{HERRERIAS CAVE}

Herrerias Cave is located in NW Spain (Llanes, Asturias), $4^{\circ} 45^{\prime} \mathrm{W}, 43^{\circ} 24^{\prime} \mathrm{N}$ (Figure 1). The cave meanders over a short distance with a horizontal extent less than $200 \mathrm{~m}$. A small stream flows through the cave year-round. The watershed of the river $\left(3.6 \mathrm{~km}^{2}\right)$ is host to agricultural, recreational and residential land uses. A transfer station is located directly over part of the cave and is characterised by significant truck traffic. The entrance of the cave lies under forests of laurel and the area of dripwater collection lies under a cow pasture. A spring is located at the south of the massif (Figure 4). The karstic massif is located in Carboniferous Limestone (Cuera and Barcaliente Formations) trending E-W (Marquinez, 1989) that shows the development of open karren linked to minor fractures.

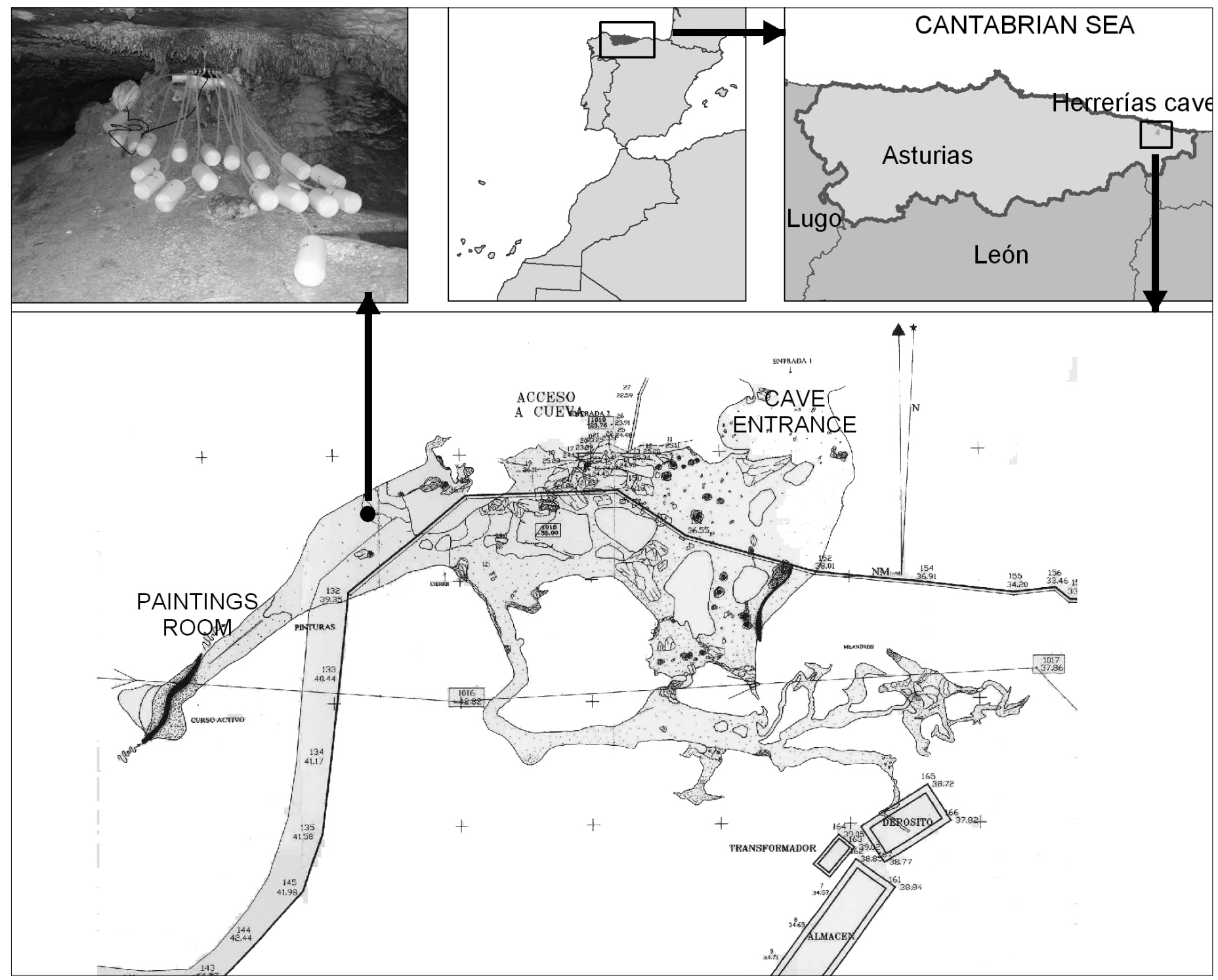

Fig. 4. Herrerias Cave with the location of the sample collector and a detail of the sampling site. 


\begin{tabular}{|c|c|c|c|c|c|c|c|c|}
\hline & $\mathrm{Ca}^{2+}$ & $\mathrm{Mg}^{2+}$ & $\mathrm{HCO}_{3}^{-}$ & $\mathrm{Cl}^{-}$ & $\mathrm{NO}_{2}^{-}$ & $\mathrm{NO}_{3}^{-}$ & $\mathrm{SO}_{4}^{2-}$ & TOC \\
\hline 06-02-07 & 173.00 & 3.46 & 281.8 & 20.24 & 0.09 & 4.58 & 36.97 & 2.40 \\
\hline 08-02-07 & 102.00 & 2.84 & 277.0 & 15.14 & 0.04 & 5.88 & 24.77 & 2.16 \\
\hline $10-02-07$ & 108.10 & 2.64 & 255.4 & 14.75 & 0.06 & 7.62 & 23.05 & 3.31 \\
\hline $12-02-07$ & 124.30 & 2.61 & 298.5 & 14.89 & 0.06 & 5.34 & 20.33 & 1.99 \\
\hline 14-02-07 & 112.30 & 2.85 & 304.1 & 16.23 & 0.03 & 9.04 & 22.60 & 3.02 \\
\hline 16-02-07 & 139.30 & 2.81 & 143.1 & 15.15 & 0.49 & 11.68 & 21.13 & 3.19 \\
\hline $18-02-07$ & 127.20 & 2.78 & 185.3 & 14.37 & 0.10 & 13.80 & 20.27 & 2.58 \\
\hline 20-02-07 & 116.20 & 3.80 & 257.5 & 18.58 & 0.15 & 8.00 & 35.15 & 1.80 \\
\hline $22-02-07$ & 115.60 & 3.33 & 272.3 & 18.51 & 0.05 & 8.26 & 29.46 & 2.48 \\
\hline $24-02-07$ & 117.00 & 3.32 & 276.2 & 17.43 & 0.03 & 6.56 & 30.25 & 1.62 \\
\hline 26-02-07 & 118.90 & 2.76 & 317.4 & 16.47 & 0.14 & 9.33 & 20.80 & 1.73 \\
\hline $28-02-07$ & 127.20 & 2.72 & 304.1 & 15.16 & 0.16 & 12.56 & 19.59 & 1.62 \\
\hline 02-03-07 & 106.90 & 2.86 & 357.7 & 15.06 & 0.03 & 13.70 & 20.37 & 1.75 \\
\hline 04-03-07 & 129.60 & 2.88 & 260.9 & 15.16 & 0.03 & 14.79 & 20.90 & 3.11 \\
\hline 06-03-07 & 111.20 & 2.98 & 317.0 & 15.07 & 0.23 & 15.63 & 21.24 & 3.92 \\
\hline 08-03-07 & 96.23 & 2.87 & 262.5 & 23.48 & 0.20 & 4.00 & 25.77 & 1.75 \\
\hline $10-03-07$ & 97.12 & 3.00 & 272.1 & 20.56 & 0.16 & 5.99 & 28.54 & 1.91 \\
\hline 12-03-07 & $\ldots$ & 3.02 & 195.3 & 19.56 & 0.08 & 5.61 & 29.29 & 15.56 \\
\hline 14-03-07 & 99.12 & 2.59 & 240.7 & 18.24 & 0.06 & 2.20 & 24.41 & 2.20 \\
\hline $16-03-07$ & 106.50 & 2.63 & 216.7 & 19.12 & 0.05 & 6.57 & 23.00 & 4.39 \\
\hline 18-03-07 & 99.62 & 2.94 & 263.3 & 23.60 & 0.29 & 4.20 & 25.05 & 1.90 \\
\hline 20-03-07 & 137.30 & 3.35 & 283.0 & 21.05 & 0.17 & 5.40 & 32.95 & 2.16 \\
\hline 22-03-07 & 122.10 & 3.56 & 292.3 & 20.04 & 0.10 & 4.38 & 35.22 & 2.11 \\
\hline 24-03-07 & 190.50 & 3.54 & 288.2 & 19.72 & 0.10 & 4.42 & 35.34 & 2.13 \\
\hline $26-03-07$ & 127.80 & 3.62 & 262.7 & 19.21 & 0.86 & 5.92 & 29.97 & 2.25 \\
\hline $28-03-07$ & 120.80 & 3.61 & 260.6 & 19.08 & 0.41 & 8.28 & 29.97 & 2.18 \\
\hline $30-03-07$ & 119.80 & 3.62 & 248.4 & 19.27 & 0.58 & 6.30 & 30.27 & 2.23 \\
\hline 01-04-07 & 104.80 & 3.25 & 283.9 & 17.22 & 0.42 & 5.63 & 30.04 & 2.35 \\
\hline 03-04-07 & $\ldots$ & $\ldots$ & 104.0 & 19.10 & 0.08 & 5.74 & 25.44 & 19.07 \\
\hline 05-04-07 & $\ldots$ & $\ldots$ & 110.2 & 18.84 & 0.04 & 7.87 & 25.58 & 28.76 \\
\hline $13-04-07$ & 125.20 & 2.00 & 156.7 & 14.16 & 0.73 & 3.72 & 16.42 & 3.19 \\
\hline 17-04-07 & $\ldots$ & $\ldots$ & 109.7 & 19.29 & 0.75 & 6.60 & 25.95 & 8.59 \\
\hline $21-04-07$ & 101.60 & 2.84 & 208.1 & 15.19 & 0.13 & 5.78 & 24.22 & 4.33 \\
\hline $25-04-07$ & $\ldots$ & $\ldots$ & 93.0 & 17.91 & 0.01 & 4.65 & 31.08 & 17.31 \\
\hline $27-04-07$ & 114.60 & 3.00 & 171.3 & 16.39 & 0.15 & 5.69 & 28.41 & 3.45 \\
\hline 01-05-07 & 99.02 & 2.29 & 166.4 & 15.27 & 0.21 & 4.82 & 19.41 & 3.19 \\
\hline 03-05-07 & 96.23 & 2.62 & 172.9 & 20.47 & 0.09 & 4.57 & 27.71 & 3.13 \\
\hline 05-05-07 & 163.80 & 3.15 & 95.0 & 20.93 & 0.08 & 3.80 & 37.03 & 12.64 \\
\hline 07-05-07 & 90.14 & 2.07 & 219.6 & 14.13 & 0.18 & 5.20 & 14.40 & 3.07 \\
\hline 09-05-07 & 111.70 & 3.24 & 226.2 & 19.25 & 0.24 & 5.97 & 30.59 & 2.81 \\
\hline $11-05-07$ & 109.20 & 3.22 & 259.9 & 15.68 & 0.35 & 4.66 & 27.92 & 2.63 \\
\hline $13-05-07$ & 111.30 & 3.46 & 185.05 & 15.946 & 0.08 & 5.35 & 26.118 & 2.66 \\
\hline $15-05-07$ & 105.70 & 3.03 & 157.45 & 13.084 & 0.62 & 2.06 & 22.812 & 2.386 \\
\hline $17-05-07$ & 104.70 & 3.51 & 105.10 & 14.109 & 0.54 & 2.36 & 29.455 & 2.622 \\
\hline $19-05-07$ & 117.20 & 3.13 & 178.80 & 14.956 & 0.10 & 9.38 & 20.08 & 1.949 \\
\hline 21-05-07 & 175.50 & 3.13 & 234.95 & 13.074 & 0.67 & 5.46 & 18.318 & 1.887 \\
\hline $23-05-07$ & 107.40 & 2.61 & 116.30 & 16.25 & 0.75 & 7.57 & 22.555 & 2.647 \\
\hline $25-05-07$ & 113.70 & 3.12 & 207.15 & 17.272 & 0.16 & 9.26 & 23.074 & 2.48 \\
\hline $27-05-07$ & 114.50 & 3.14 & 197.95 & 17.107 & 0.05 & 10.63 & 22.458 & 2.149 \\
\hline 29-05-07 & $\ldots$ & $\ldots$ & 96.90 & 16.404 & 0.03 & 10.00 & 21.244 & 49.09 \\
\hline 01-06-07 & $\ldots$ & $\ldots$ & 80.50 & 15.90 & $\ldots$ & 8.97 & 19.642 & 12.66 \\
\hline 03-06-07 & 116.40 & 3.14 & 193.40 & 15.648 & 1.59 & 8.70 & 21.05 & 2.21 \\
\hline 05-06-07 & 108.50 & 2.71 & 114.50 & 9.665 & 0.68 & 0.86 & 18.69 & 2.216 \\
\hline 07-06-07 & 102.80 & 2.68 & 142.70 & 12.268 & 0.40 & 1.87 & 17.91 & 3.06 \\
\hline 09-06-07 & 120.30 & 2.84 & 242.65 & 14.50 & 0.08 & 7.43 & 20.19 & 2.011 \\
\hline $11-06-07$ & $\ldots$ & $\ldots$ & & 39.83 & 17.98 & 4.37 & 19.52 & $\ldots$ \\
\hline $15-06-07$ & 107.30 & 2.74 & 178.70 & 14.92 & 7.34 & 1.63 & 7.11 & 2.486 \\
\hline 17-06-07 & 118.00 & 3.11 & 170.80 & 16.29 & 0.34 & 11.04 & 21.07 & 2.40 \\
\hline $19-06-07$ & 90.19 & 2.67 & 242.25 & 12.33 & 0.40 & 0.56 & 23.18 & 3.081 \\
\hline $21-06-07$ & 95.53 & 2.71 & 153.50 & 12.36 & 0.36 & 3.00 & 23.61 & 4.284 \\
\hline $23-06-07$ & 113.00 & 2.96 & 195.35 & 18.66 & 0.79 & 12.99 & 22.92 & 2.713 \\
\hline $25-06-07$ & $\ldots$ & $\ldots$ & 87.65 & 19.00 & 0.27 & 16.41 & 22.01 & 7.693 \\
\hline $27-06-07$ & 80.07 & 2.25 & 165.10 & 9.76 & 0.36 & 0.60 & 19.89 & 3.255 \\
\hline
\end{tabular}

Table 2. Analytical values for the selected parameters in Herrerías Cave. All concentrations in $\mathrm{mg} / \mathrm{L}$ 


\section{Methodology}

The same collector designed for Pindal Cave was installed in Herrerias Cave on February 2007 (Figure 4). Samples during the period February-June 2007 have been selected for this paper (Table 2). Ions were measured at the laboratory of Hydrogeology of the University of Málaga via Ionic Chromatography (IC). Total organic carbon (TOC) was also measured with a TOC analyzer. Graphs of temporal evolution were constructed for the selected parameters in order to analyze the relationships between the hydrochemical data.

\section{Results and discussion}

The analysis of the collected samples (Figure 5) show a predominance of bicarbonate and calcium related to lithology of the area. However, other hydrochemical constituents are connected to rainfall or pushing effect from the soil towards the dripwater points or to contamination processes related to agriculture or farming activities (nitrite, nitrate, TOC and chloride).

Values of $\mathrm{NO}_{3}{ }^{-}$and $\mathrm{SO}_{4}{ }^{2-}$ are higher than could be expected in a system with a carbonate lithology. Natural sources of these anions are nitrate salts or evaporites (gypsum). In the latter case, the presence of evaporites or metallic sulphides in carbonates is not unusual which could explain the elevated concentrations of sulphate by dissolution and/or oxidation of minerals.

However, it is uncommon to find nitrate salts at such a concentration in carbonate rocks. In any case, the increase of solutes in rainfall by evaporation processes in the soil should not be the only mechanism that explains the high concentrations of $\mathrm{NO}_{3}{ }^{-}$and $\mathrm{SO}_{4}{ }^{2-}$, because it requires high evaporation rates and consequently, low infiltration volumes of the rainfall are necessary, and this situation is not typical in karst areas of this sector of Spain.

Concerning sulphate, concentration varies between 17 and $35 \mathrm{mg} / \mathrm{L}$. During high recharge periods, it is possible to find low values ( $7 \mathrm{mg} / \mathrm{L})$, e. g. in mid-June, or increases in the concentration, such as during rainfall periods recorded at the beginning of the research. $\mathrm{NO}_{3}{ }^{-}$concentrations range from 4 to $8 \mathrm{mg} / \mathrm{L}$, but it is not unusual to find periods of even 1 week (February, February-March or June) with concentrations above $14 \mathrm{mg} / \mathrm{L}$. Also, significant values below $1 \mathrm{mg} / \mathrm{L}$ at the end of the research period were measured.

Unlike the situation usually observed in karst groundwater, where the presence of nitrite is below detection limits or very low, this specie was always
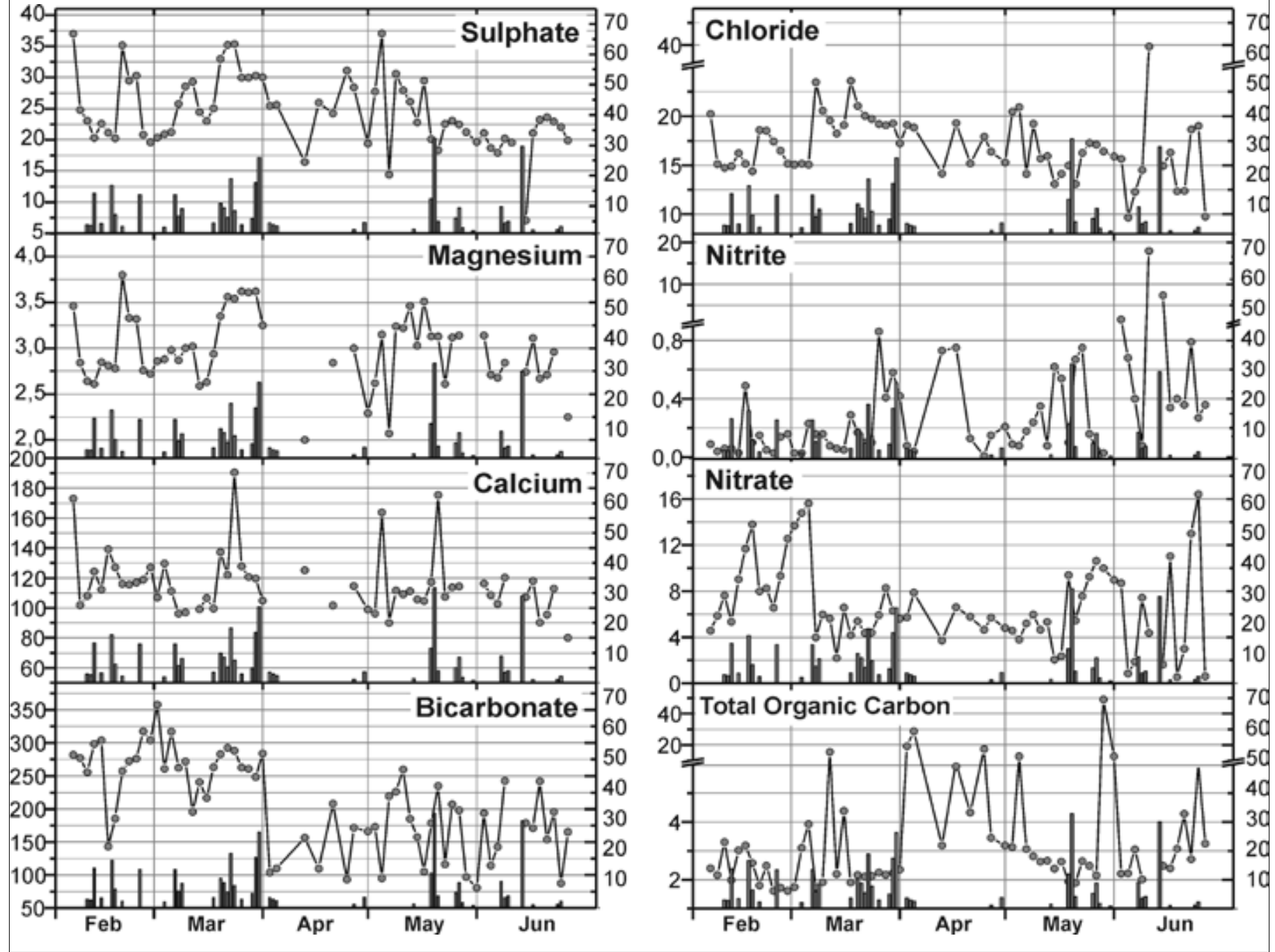

Fig. 5. Evolution of selected hydrochemical parameters in Herrerias Cave for the period February-June 2007. All parameters in mg/L (left axis). Rainfall (grey bars) in $\mathrm{mm} /$ day (right axis) 
detected in drip-waters during this study. The detection of this constituent must be explained by the relatively thin unsaturated zone over the drip water point, and consequently most of the natural organic nitrogen in the form of nitrite is not oxidized and arrives in this form at the drip water point. In general, this component is detected in concentrations below $0.3 \mathrm{mg} / \mathrm{L}$ to even $0.8 \mathrm{mg} / \mathrm{L}$ during some short fluxes of time. The low concentration of nitrite is generally related to high rainfall recharges (end of March). However, the nitrogen species may appear in high concentrations during low or no recharge periods, such as was measured in mid-April ( $0.8 \mathrm{mg} / \mathrm{L})$ or beginning of June ( $17 \mathrm{mg} / \mathrm{L})$ for nitrite or end of June $(14-16 \mathrm{mg} / \mathrm{L})$ for nitrate. It is remarkable that the maximum value of $\mathrm{NO}_{2}^{-}$(June) is related to the highest content of $\mathrm{Cl}^{-}$of the entire research period (40 $\mathrm{mg} / \mathrm{L})$ and the lowest value of $\mathrm{SO}_{4}{ }^{2-}(7 \mathrm{mg} / \mathrm{L})$.

Background values for TOC are above typical concentrations found in karstic groundwater. TOC values in Herrerias cave ranged between 1 and $4 \mathrm{mg} /$ $\mathrm{L}$, but at least 7 values reached concentrations of more than $15 \mathrm{mg} / \mathrm{L}$. These concentrations are not always related to rainfall periods. In fact, during the latter half of April, drip water reached $20 \mathrm{mg} / \mathrm{L}$ of TOC in a period with no rainfall. In addition, there is an inverse correlation between the peaks and periods of higher TOC concentrations and dissolved inorganic carbon $\left(\mathrm{HCO}_{3}^{-}\right)$as well. This correlation can be appreciated during the end of May-beginning of June, where TOC concentrations reached the highest value $(50 \mathrm{mg} / \mathrm{L}$, while the $\mathrm{HCO}_{3}{ }^{-}$reaches its minimum $(80 \mathrm{mg} / \mathrm{L})$.

When the first rainfall of the research period (February-March) introduced volumes of water into the system, the $\mathrm{Cl}^{-}$concentration decreased because of the dilution effect, but an increase of $\mathrm{NO}_{3}^{-}, \mathrm{Mg}^{2+}$, and $\mathrm{SO}_{4}{ }^{2-}$ was observed. This pushing effect is produced because water stored in the soil or unsaturated zone above the drip point is replaced and then mobilized downwards as a result of fresh rainfall.

The background values of TOC could be explained by the reduced thickness of the vadose zone. This would allow water percolation from soils with high organic matter concentrations. Much of the observed evolutions of $\mathrm{NO}_{3}^{-}, \mathrm{NO}_{2}^{-}$, TOC and $\mathrm{Cl}^{-}$are related to rainfall episodes. However, there are some events difficult to link with the rainfall recharge, as $\mathrm{NO}_{2}^{-}$peaks of mid-April or beginning of June, $\mathrm{NO}_{3}$ concentrations during the end of June, TOC values at the end of May or June or $\mathrm{Cl}^{-}$concentrations of near $40 \mathrm{mg} / \mathrm{L}$ of June. Bearing in mind that the area in which this cavity is located contains (1) agricultural, recreational and residential land uses, (2) a transfer station with significant truck traffic and (3) a cow pasture area over the cave, it is expected that all these periods will exhibit significantly high concentrations of nitrogenous compounds, chloride and organic content which must be related to different releases of wastes (livestock waste, fertilizers or waste waters).

The inverse correlation between organic (TOC) and inorganic carbon $\left(\mathrm{HCO}_{3}^{-}\right)$is a hydrochemical consequence of the contamination-producing processes. High concentrations of TOC and low concentrations of $\mathrm{HCO}_{3}^{-}$, as observed in this study, imply a fast transfer of water from the surface to groundwater. This fast transfer does not allow the mineralization of organic carbon (high TOC) and causes a short interaction between water and carbonated minerals (low $\mathrm{HCO}_{3}^{-}$). In the case of a contamination of cationic metals or any other " $\mathrm{pH}$-dependent" compound, the buffer effect of the calcocarbonic system will be affected because the attenuation of the inorganic carbon. At the same time, an increase of the organic carbon and, consequently, the capacity of formation of complexes between organic matter and metals will be enhanced. This hydrochemical situation is not favourable for the attenuation of these contaminants because metals would be transported faster and with a lower attenuation towards the groundwater.

\section{TITO BUSTILLO CAVE}

\section{Setting}

Tito Bustillo Cave, located in Northern Spain, $5^{\circ}$ $4^{\prime} \mathrm{W}, 43^{\circ} 28^{\prime} \mathrm{N}$, was discovered in 1968 and opened in 1969 for tourist use due to the great interest of its prehistoric cave paintings. It is located in a karstic massif developed in the Escalada Limestone of Carboniferous age, affected by important faults trending E-W to ESE-WNW and NW-SE to NNWSSE (Alonso et al., 1999). At the top, this massif is a remnant of a marine erosion terrace $(70-80 \mathrm{~m}$ above sea level) in which dolines and karren are widely developed. Fluvial and gravity processes also influenced the Quaternary evolution of the area. The active level of the cave is being eroded by the San Miguel River, which has a superficial basin of 9.6 $\mathrm{km}^{2}$ and sinks into the massif through the Gorgocera swallet, flowing from $\mathrm{W}$ to $\mathrm{E}$. The resurgence of the river is located at the left margin of the Sella Estuary, next to the visitor centre. The structural anisotropy of the massif is probably the main conditioning factor of speleogenesis and is represented by bedding (SO, dipping $14^{\circ}-65^{\circ}$ to S-SSW) and two main fracture systems (F1, N140E, vertical or dipping SW and F2, N20E-N70E, dipping $30^{\circ}$ to the SE) (Jiménez-Sánchez et al., 2004).

Several hydrochemical and human impact studies were carried out in this cave and surroundings (Martinez San Miguel, 1990; Otal and Buergo, 1991). Hoyos et al. (1996) studied the environmental impact of tourist use as well as some hydrochemical aspects. Finally, Jiménez Sanchez et al. (2002b) characterized the waters from a hydrogeological point of view and studied the temporal evolution of hydrochemical parameters in order to evaluate the influence of land use and measure water degradation in the cave.

The hydrological system is recharged by rainfall at the top of the massif, infiltrating through swallets and karren, as well as by the San Miguel River basin. Therefore, land uses must be evaluated in the river basin and on the exokarst on top of the cave. In both cases, agricultural, farming, touristic and residential uses are detected. Also, illegal wastes are located 
in some dolines in Ardines Massif, above the cave. Contamination risks must also take into account the natural dynamics of the river and flood peaks, which reaches discharges of $80 \mathrm{~m}^{3} / \mathrm{s}$ (Martinez San Miguel, 1990). Gorgocera swallet is frequently covered by trash and debris that retards river water infiltration into the massif. The problem grows when the level of the water rises during flood peaks and the capacity of infiltration of the swallet is exceeded, causing the occurrence of an ephemeral lake. Water enters at the active level and rises, leading to the flooding of the touristic level, and thus impeding the cave visits. Liquified livestock waste is periodically washed in from the watershed and transported to the visited level, intensifying the gravity of the problem.

\section{Methodology}

In the study area, diffuse contamination sources were linked to pasture with livestock use in the fluvial basin and on top of the massif. However, the main risk is posed by concentrated sources located directly above the cave and includes villages, landfills and stables without wastewater treatment and malfunctioning septic tanks.

Consequently, we studied $\mathrm{N}$ (nitrite, nitrate, ammonium), P, and chemical oxygen demand (COD) although more parameters were also measured in the laboratory (Jiménez-Sánchez et al. 2002). As in other karst areas (Thorn and Coxon, 1992; Hunter et al. 2004), some bacteriologicalanalyses were also made in order to evaluate possible sources of faecal contamination. A permanent monitoring system was designed, with installation of 2 $\mathrm{L}$ bottles with funnels to collect dripwaters at 12 points near prehistoric cave paintings and another one outside of the cave to collect rainfall (Figure 6). Eighteen sampling campaigns were carried out in 1999, between March 18 and November 3, with a two week to 1 month frequency. During field work, samples of fluvial water were taken in two locations at the Gorgocera swallet (point 15, Figure 6) and at the resurgence of the river from the karstic massif (point 14, Figure 6). Also, a static level of water inside the cave was sampled (point 13, Figure 6). Microbiological parameters were analysed three times (one in June and two in September). Two samples were taken in the river entrance (point 15, Figure 6) and the others inside the cave (point 2, Figure 6) and in the resurgence point, near the cave entrance (point 14, Figure 6).

\section{Results and discussion}

Table 3 shows the mean values obtained during the research in all the analyzed points for oxidability and $\mathrm{N}$ compounds. The values for $\mathrm{P}$ compounds were always lower than $0.2 \mathrm{mg} / \mathrm{L}$. Evidence of water degradation can be found in several occasions. On April 15 1999, the drip water sample 12, located in the Painting Room, attained a maximum of $0.59 \mathrm{mg} / \mathrm{L}$ in ammonium and $0.13 \mathrm{mg} / 1 \mathrm{NO}_{2}^{-}$. These data suggest the proximity of a discrete source of organic waste from a stable located directly above the cave. The river samples also vary spatially in ammonium concentration. As an example, on June 17 1999, the value measured in Gorgocera swallet (point 15), where the river infiltrates to the active level, was $0.1 \mathrm{mg} / \mathrm{L}$, while for the same day, $0.66 \mathrm{mg} /$ $\mathrm{L}$ was measured at the resurgence point, (sample 14) indicating addition of ammonia along the trajectory.

The bacteriological analyses results show a great variability. As an example, the data for June 2 1999 show an important peak in the bacteriological concentrations of faecal contamination, with 1000 colony forming units $/ 100 \mathrm{~mL}$ at point 15 (Gorgocera Swallet, Figure 6) and 1400 colony forming units / 100 $\mathrm{mL}$ in the resurgence point (point 14, Figure 6). Also, these data indicate increasing contamination along the flow path of the stream through the karst conduit, due to vertical percolation of contaminants from the stables situated above the cave.

\section{Setting}

\section{LAS MARAVILLAS CAVE}

Las Maravillas Cave is situated in Aracena (Huelva province), in the south-west corner of Spain $\left(6^{\circ}\right.$ $\left.33^{\prime} \mathrm{W}, 37^{\circ} 53^{\prime} \mathrm{N}\right)$, and is a representative site of geological interest of the Natural Park of the Sierra de Aracena y Picos de Aroche (Figure 1). Here, the formations of the cave constitute its main attraction. Apart from its scientific and educational value, the natural monument is a significant contribution to the economic resources of the region. At the same time, the local administration charged with management of the cave is trying to make its tourist exploitation compatible with the conservation requirements, by means of a series of corrective measures designed to ameliorate the damaging effects of human presence in the cave.

The Cave is developed in a Lower Cambrian small marble outcrop affected by high T-amphibolite metamorphism and included in the Aracena Massif at the sourthern edge of Ossa-Morena Area. The marbles foliation trends N120E, trolling the main karstification directions. The underground complex has a known length of $2,130 \mathrm{~m}$. Discovered during the middle part of the nineteenth century, and prepared for tourist

\begin{tabular}{|c|c|c|c|c|c|c|c|c|c|c|c|c|c|c|c|}
\hline Sample points & 1 & 2 & 3 & 4 & 5 & 6 & 8 & 9 & 10 & 11 & 12 & 13 & 14 & 15 & 16 \\
\hline $\mathrm{NH}_{4}^{+}(\mathrm{mg} / \mathrm{L})$ & 0.1 & 0.1 & 0.03 & 0.1 & 0.1 & 0.1 & 0.1 & 0.1 & 0.04 & & 0.1 & 0.3 & 0.2 & 0.2 & 0.4 \\
\hline $\mathrm{NO}_{2}^{-}(\mathrm{mg} / \mathrm{L})$ & 0.1 & 0.04 & 0.1 & 0.1 & 0.1 & 0.1 & 0.01 & 0.02 & 0.1 & & 0.1 & 0.1 & 0.1 & 0.1 & 0.03 \\
\hline $\mathrm{NO}_{3}^{-}(\mathrm{mg} / \mathrm{L})$ & 5.7 & 2 & 1.5 & $<10$ & $<10$ & $<10$ & $<10$ & $<10$ & $<8.6$ & $<8.7$ & $<10$ & 3.5 & 9 & $<10$ & $<10$ \\
\hline Oxidability $\left(\mathrm{mg} / \mathrm{L} \mathrm{O}_{2}\right)$ & 1 & 1.1 & 1.1 & 1.5 & 1 & 1.2 & 0.9 & 1 & 1 & 0.4 & 1.3 & 3.7 & 3.7 & 2.6 & 2.5 \\
\hline
\end{tabular}

Table 3. Mean values for $\mathrm{N}$ compounds and oxidability in Tito Bustillo Cave 


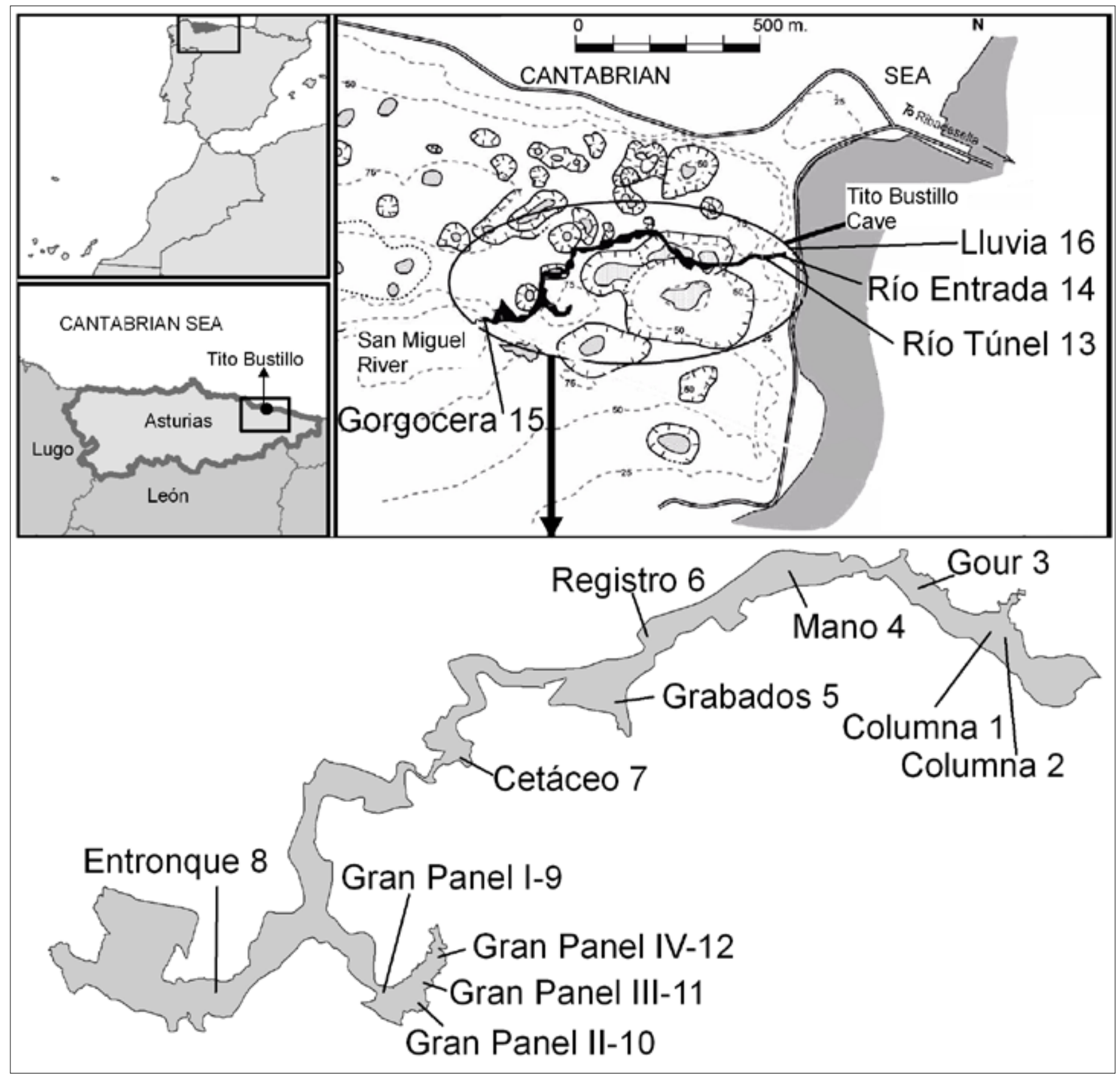

Fig. 6. Sample points in Tito Bustillo Cave.

visits in 1911 (Martin-Rosales et al., 2007), the cave is particularly well known for its extraordinary abundance and variety of both vadose and subaqueous speleothems. In the zones at more distant parts from the cave entrance, abundant acicular aragonite and calcite eccentrics may be found (Martin-Rosales et al., 1995). Although its development is predominantly horizontal, this cave has at least three distinguishable levels of karstification, vertically superimposed. The first two levels correspond primarily to the presentday tourist route of $1,000 \mathrm{~m}$ in length.

The touristic activity began in 1911. The cave received a maximum of 150,000 visitors/year, contributing to the economical progress of the area. However, the environmental degradation in the cave led the Municipal Authorities to start the development of a research program in 1993 in order to evaluate the environmental degradation (Pulido-Bosch et al., 1997).
The data in this work come from the last research contract established between Granada University and the Aracena Municipality and includes some of the data collected and analyzed during 2006.

\section{Methodology}

Forty one water samples were taken for hydrochemical study in Maravillas Cave from October 2005 to September 2006 at 12 points depicted in Figure 7. These points include rainfall, phreatic water from the Cave (Gran Lago point, Figure 7), springs that could be draining the cave and the aquifer in which it is developed, and drip and gour waters from the vadose zone of the cave. Most of the samples were taken during three sampling campaigns carried out in 2006: February, 7-8, March, 28-29 (high water samples) and September, 26-27 (low water samples). The rainfall samples were preserved from evaporation by a $0.5 \mathrm{~cm}$ thick layer of liquid vaseline which floated 


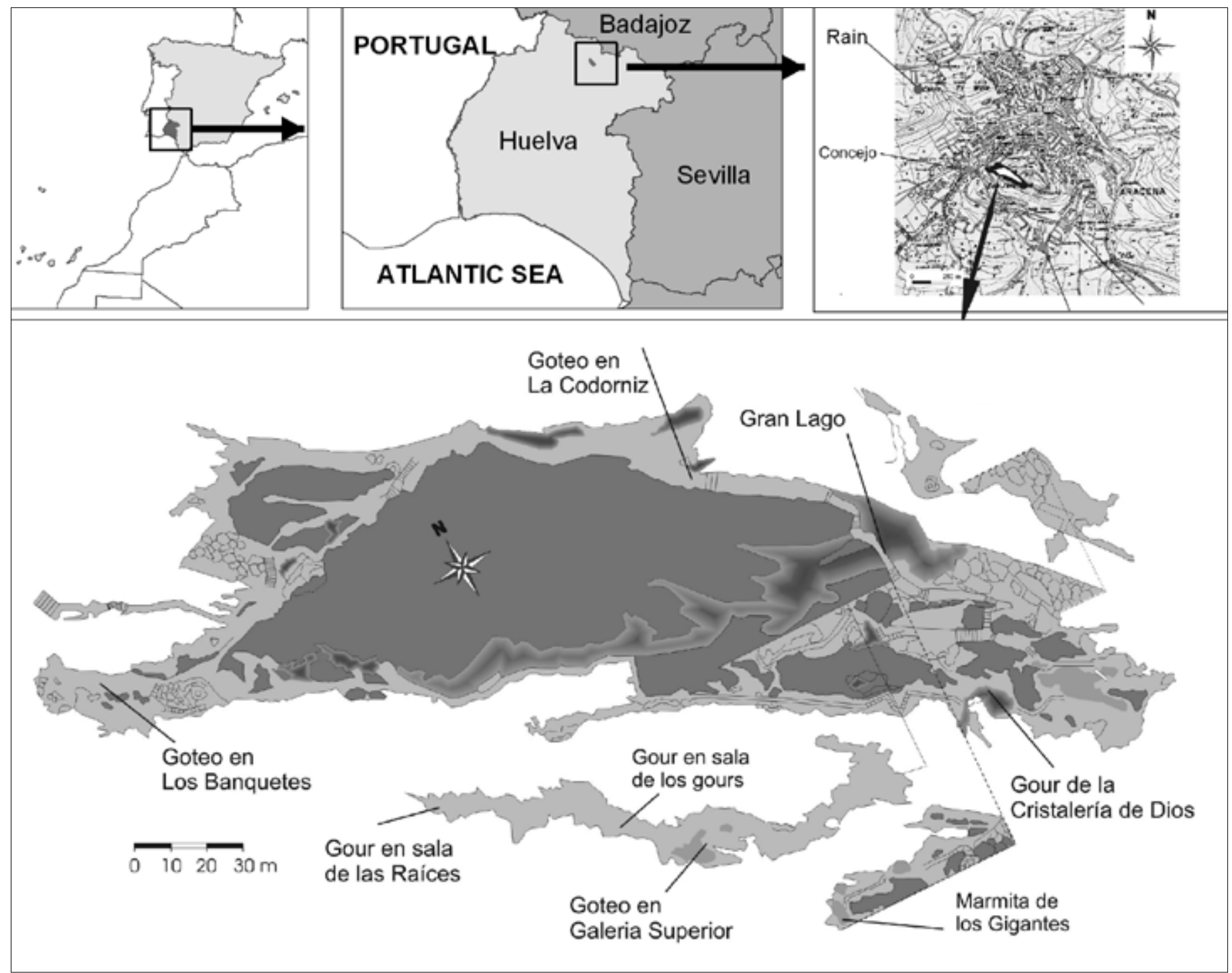

Fig. 7. Setting and sample points in Maravillas Cave

above the rainwater. We used a Multi 340i (WTW) with a redox potencial electrode (Sentix ORP) to measure in situ $\mathrm{pH}$, conductivity, temperature, dissolved oxygen and Eh. We also measured $\mathrm{HCO}_{3}{ }^{-}$through volumetric titration in $100 \mathrm{~mL}$ of water with $0.05 \mathrm{~N} \mathrm{HCl}$ and methyl orange as an indicator. At each point, two replicates of $250 \mathrm{~mL}$ were retrieved for laboratory analysis. One replicate was conserved with several drops of nitric acid to bring the $\mathrm{pH}$ to 2 for cation analysis and the other replicate was used for anion analysis. Concentration of ions were measured via Ionic Cromatography (IC). Total organic carbon (TOC) was also measured with a TOC analyzer

\section{Results and discussion}

Analytical samples results appear in Table 4. In general, the parameters measured in this study indicate that the sampled waters are weakly to moderately mineralized $(0.22$ and $0.65 \mathrm{~g} / \mathrm{L}$ total dissolved solids). From the data collected, the water would meet drinking water standards, although criteria of microbiological, heavy metal, pesticide and other persistent organic compounds were not examined. However, it is worth mentioning the high nitrite $\left(\mathrm{NO}_{2}^{-}\right)$and nitrate $\left(\mathrm{NO}_{3}^{-}\right)$levels, that will be explained in the following paragraphs.
Samples collected on March 28, 2006 exhibited high nitrite concentration, in excess of drinking water standards $(0.1 \mathrm{mg} / \mathrm{L})$ in all samples taken in the vadose zone of the cave, including dripwater and gours except the gour of the sala de las Raices location (Table 4). Except in the Marmita de los Gigantes, this situation is not reproduced in other samples. The samples with nitrite concentrations above $0.1 \mathrm{mg} / \mathrm{L}$ always have low Eh values coinciding with more reducing conditions. This is consistent with a nitrogen source from organic matter, for example, from wastewater or livestock waste, because decomposition of such waste has a high oxygen demand. Nitrite concentrations are not positively correlated with high nitrate concentrations; the locations which had high nitrite concentrations on 28 March 2006 possessed nitrate concentrations similar to those measured on other dates when nitrite concentrations were lower. This could be related to 1) the low values of Eh measured in the same campaign and 2) the water percolation from soils with high nitrite concentrations that would enter into the karstic system after the rainfall peaks of March. In fact, during March 2006, the volume of rainfall recorded by a rain gauge installed by the authors above the cave was $187 \mathrm{~L} / \mathrm{m}^{2}$. It can be remarked that this was 


\begin{tabular}{|c|c|c|c|c|c|c|}
\hline Sampling point & DATE & $\mathrm{Cl}^{-}$ & $\mathrm{SO}_{4}^{2-}$ & $\mathrm{NO}_{3}^{-}$ & $\mathrm{NO}_{2}^{-}$ & TOC \\
\hline \multirow{6}{*}{$\begin{array}{c}\text { Lluvia } \\
\text { (Depósito de } \\
\text { agua) }\end{array}$} & $21 / 10 / 2005$ & 1.0 & 3.2 & 1.7 & & 0.398 \\
\hline & $12 / 11 / 2005$ & 1.0 & 1.7 & 1.1 & & 0.513 \\
\hline & $21 / 12 / 2005$ & 1.4 & 1.0 & 0.0 & & 1.747 \\
\hline & $07 / 02 / 2006$ & 0.9 & 1.4 & 0.9 & 0.000 & 1.320 \\
\hline & $29 / 03 / 2006$ & 2.4 & 6.0 & 0.3 & 0.000 & 2.219 \\
\hline & $26 / 09 / 2006$ & 2.9 & 3.8 & 0.8 & 0.000 & 0.000 \\
\hline \multirow{6}{*}{ Gran Lago } & $21 / 10 / 2005$ & 24.5 & 55.0 & 34.9 & & 0.311 \\
\hline & $12 / 11 / 2005$ & 24.6 & 55.6 & 35.1 & & 0.247 \\
\hline & $21 / 12 / 2005$ & 22.7 & 52.1 & 32.4 & & 0.333 \\
\hline & $07 / 02 / 2006$ & 23.2 & 53.5 & 32.4 & 0.000 & 0.440 \\
\hline & $28 / 03 / 2006$ & 19.2 & 40.9 & 30.5 & 0.000 & 0.395 \\
\hline & $27 / 09 / 2006$ & 24.5 & 48.9 & 32.4 & 0.000 & 0.321 \\
\hline \multirow{3}{*}{$\begin{array}{l}\text { Fuente del } \\
\text { Concejo }\end{array}$} & $08 / 02 / 2006$ & 34.2 & 52.5 & 42.9 & 0.000 & 0.492 \\
\hline & $29 / 03 / 2006$ & 37.1 & 44.3 & 47.5 & 0.000 & 0.334 \\
\hline & $27 / 09 / 2006$ & 33.3 & 46.0 & 41.2 & 0.000 & 0.286 \\
\hline \multirow{2}{*}{$\begin{array}{l}\text { Fuente de } \\
\text { La Albuera }\end{array}$} & $29 / 03 / 2006$ & 49.3 & 92.7 & 21.1 & 0.000 & 0.843 \\
\hline & $27 / 09 / 2006$ & 47.9 & 94.5 & 15.5 & 0.000 & 0.632 \\
\hline \multirow{3}{*}{$\begin{array}{c}\text { Fuente de la } \\
\text { Zulema }\end{array}$} & $08 / 02 / 2006$ & 70.3 & 85.3 & 13.5 & 0.000 & 0.465 \\
\hline & $29 / 03 / 2006$ & 24.6 & 87.6 & 37.9 & 0.000 & 0.400 \\
\hline & $27 / 09 / 2006$ & 26.0 & 94.3 & 37.4 & 0.000 & 0.410 \\
\hline \multirow{3}{*}{$\begin{array}{l}\text { Goteo Galería } \\
\text { Superior }\end{array}$} & $08 / 02 / 2006$ & 5.0 & 9.7 & 37.0 & 0.045 & 0.337 \\
\hline & $28 / 03 / 2006$ & 4.1 & 13.9 & 22.3 & 0.164 & 0.575 \\
\hline & $26 / 09 / 2006$ & 6.6 & 9.8 & 23.7 & 0.051 & 0.000 \\
\hline \multirow{3}{*}{$\begin{array}{l}\text { Goteo Sala de } \\
\text { Los Banquetes }\end{array}$} & $07 / 02 / 2006$ & 6.0 & 49.7 & 47.1 & 0.011 & 0.210 \\
\hline & $28 / 03 / 2006$ & 6.1 & 58.5 & 30.1 & 0.113 & 0.254 \\
\hline & $27 / 09 / 2006$ & 3.8 & 27.1 & 39.1 & 0.000 & 0.139 \\
\hline \multirow{3}{*}{$\begin{array}{l}\text { Goteo de la } \\
\text { Codorniz }\end{array}$} & $08 / 02 / 2006$ & 4.0 & 4.3 & 33.1 & 0.032 & 0.240 \\
\hline & $28 / 03 / 2006$ & 3.9 & 8.7 & 23.9 & 0.107 & 0.369 \\
\hline & $27 / 09 / 2006$ & 3.6 & 6.1 & 14.0 & 0.000 & 0.246 \\
\hline \multirow{3}{*}{$\begin{array}{c}\text { Marmita de } \\
\text { Los Gigantes }\end{array}$} & $07 / 02 / 2006$ & 3.5 & 12.1 & 6.9 & 0.121 & 0.303 \\
\hline & $28 / 03 / 2006$ & 3.6 & 14.2 & 7.3 & 0.133 & 0.361 \\
\hline & $26 / 09 / 2006$ & 3.5 & 10.7 & 8.0 & 0.029 & 0.000 \\
\hline \multirow{3}{*}{$\begin{array}{c}\text { Sala de Los } \\
\text { Gours } \\
\text { (Galería } \\
\text { Superior) }\end{array}$} & $07 / 02 / 2006$ & 5.0 & 6.5 & 34.8 & 0.089 & 0.564 \\
\hline & $28 / 03 / 2006$ & 4.2 & 11.9 & 24.2 & 0.150 & 0.382 \\
\hline & $26 / 09 / 2006$ & 3.1 & 8.9 & 16.9 & 0.038 & 0.000 \\
\hline \multirow{3}{*}{$\begin{array}{c}\text { Gour Sala de } \\
\text { las Raíces } \\
\text { (Galería } \\
\text { Superior) } \\
\end{array}$} & $07 / 02 / 2006$ & 4.4 & 5.2 & 14.4 & 0.005 & 0.117 \\
\hline & $28 / 03 / 2006$ & 4.3 & 8.9 & 7.2 & 0.000 & 0.137 \\
\hline & $26 / 09 / 2006$ & 3.8 & 4.3 & 6.9 & 0.000 & 0.139 \\
\hline \multirow{3}{*}{$\begin{array}{c}\text { Gour Cristalería } \\
\text { de Dios }\end{array}$} & $07 / 02 / 2006$ & 23.3 & 51.1 & 31.2 & 0.050 & 0.398 \\
\hline & $28 / 03 / 2006$ & 18.5 & 38.7 & 29.0 & 0.146 & 0.425 \\
\hline & $26 / 09 / 2006$ & 17.6 & 35.4 & 26.1 & 0.000 & 0.387 \\
\hline
\end{tabular}

Table 4. Analytical results for Maravillas Cave and surroundings. All parameters in mg/L. n.d. = not detected

the most rainy month of the October 2005-September 2006 series, which registered a total rainfall volume of $839 \mathrm{~L} / \mathrm{m}^{2}$.

The phreatic waters (Gran Lago and springs) have low nitrate and high (oxidizing) Eh values, but all have high nitrate concentrations though still within the drinking water standard of $50 \mathrm{mg} / \mathrm{L}$. Inside the cave in the vadose zone relatively high $\mathrm{NO}_{3}{ }^{-}$concentrations persist continuously in nearly all the dripwater samples, with the exception of the Marmita de los Gigantes point and the gour of the Sala de las Raices point (Figure 7). As a result, evidence of contamination can be established from high values of $\mathrm{NO}_{3}{ }^{-}$(higher than $47 \mathrm{mg} / \mathrm{L}$ in some of the drip points) and could be related to the proximity of water leak from urban waste pipes. The concentrations of nitrogen species suggest anthropogenic contamination of phreatic water and points in the cave near locations like the Sala of Banquetes point (Figure 7). We infer that these waters are affected by mixing with an unknown distal source of water (such as urban wastewater, slaughterhouses, livestock waste, fertilizers, etc.) which deliver chloride, sulphate, magnesium, carbon dioxide and nitrate from organic matter decomposition, etc. Otherwise, mass balance of chloride from the rain and water of Gran Lago point (Figure 7) would require an infiltration rate of only $8 \%$, which is too low for a karst terrain in the Mediterranean environment. High 
concentrations of nitrate in other points (La Codorniz point and drips and gours from the Galeria Superior, Figure 7) reflects contamination sources different from a natural source of nitrogen because a high and continuous release from these sources is needed in order to have such high nitrate levels. The absence of correlation between these ions and others also complicates their attribution. Attribution is important to remedy the contamination, especially if it is derived from anthropogenic processes.

The high nitrogen levels contribute to the eutrophisation of lakes in the cave and to the proliferation of microalgae which give a green color to the water and to extensive blooms of filamentous algae observed near submerged lights. The biological activity in the water, fostered by the excess nutrient load, heat, and light, can affect the chemistry of the groundwater, especially the $\mathrm{CO}_{2}$ concentration and saturation state of the minerals which form the speleothems which are the main attraction of the cave.

\section{SYNTHESIS AND CONCLUSIONS}

Four case studies have been presented in this work in order to check and compare different methods and results obtained in the analysis of groundwater contamination in Spanish caves. The evaluation of land use impact on groundwater contamination requires the study of parameters from the fluvial basin of stream waters entering the karstic massif and dripwaters and fluvial waters inside the cave. The parameters selected to identify human impact were chosen on the basis of land use and potential contamination risks. Thus, $\mathrm{N}$ compounds, together with $\mathrm{P}$ species, were chosen as indicators of contamination from livestock and agricultural sources. Also, other compounds such as K, COD, bacteria, and TOC are also listed in order to establish human influence on cave water contamination.

From the results of the analyses of these parameters, we infer that wastewater and livestock waste appear to be the principal sources of contamination to cave waters in the studied cases. Caves with concentrated livestock (stables) or urban and residential wastewater systems directly above exhibit the highest level of contamination, detected in elevated concentrations of nitrogen species and in some cases depressed oxygen availability in waters.

From a methodological point of view, the high temporal resolution employed in Pindal and Herrerias elucidates relationships between rainfall events and hydrochemical parameters, albeit for single drip points. The effectiveness of the method in contamination studies is optimal if the relationships between the monitored drip point and the potential sources in the exokarst are well established. As such, the temporal variations in the chemistry of the drip point are likely related to variations in the point source on top of the massif. Also, this could be very useful if a particular feature (such as prehistoric cave paintings, that are susceptible to contamination) must be surveyed and protected. The study of additional points, with lower resolution, as a groundwater stream inside the caves, swallets and resurgence points, can be useful for confirming if the drip point is representative of the aquifer system as a whole.

The other two caves (Tito Bustillo and Aracena) have a good spatial resolution of sampling, although the temporal period between the sampling campaigns is greater than 15 days. They show that it is possible to establish relationships between potentialcontaminant sources and cave-water contamination. This kind of study has the advantage of spatial distribution of potential contaminants in the caves and can also be well established and related to potential sources and geological factors. As shown by Las Maravillas Cave experience, the results can be effective for regulating the uses outside the carbonate massif and to prevent human impact. It would be desirable to combine both types of studies, together with the elaboration of landuse, hazard and vulnerability maps of the areas above the caves. Nevertheless, protecting the caves from contamination is not possible without political goodwill.

\section{ACKNOWLEDGEMENTS}

We thank Bryce Babcock and staff in the science shop at Williams College for design and construction of the battery powered dripwater samplers employed in Herrerias and Pindal caves (not commercially available). For the Pindal Cave, concentrations of $\mathrm{P}$, $\mathrm{K}$, and $\mathrm{Na}$ were measured via Inductively Coupled Plasma Emission Spectroscopy (ICP-ES) on a Thermo IRIS-ICAP DUO in axial mode at Middlebury College. Concentrations of nitrate were measured via Ionic Chromatography (IC) at Williams College and the University of Malaga. We thank Ray Coish and Jay Racela for their assistance. Herrerias and Maravillas cave analysis were measured at the laboratory of Hydrogeology of the University of Málaga with an Ionic Chromatography and a TOC analyzer. The analyses in Tito Bustillo Cave were carried out by the Public Health Laboratory of Arriondas (East Asturias) as well as in a private laboratory (Anaqua, Oviedo).

The research in Maravillas cave was funded by the Aracena Council. The climatic research in Pindal and Herreria Caves is supported by the project CAVECAL, funded by the Spanish Ministry of Education and Science (reference MEC-06-CGL2006-13327-C04-02). The rainfall data come from the INM (National Institute of Meteorology). At present, the hydrochemical research in Herrerias Cave is funded by the Asturias Government.

\section{REFERENCES}

Alonso Alonso J. L., García-Ramos J.C. \& Gutiérrez Claverol M., 1999 - Control estructural de la cavidad kárstica "La Cuevona” (Ribadesella, Asturias). In: B. Andreo, F. Carrasco, y J. J. Durán (Eds): Contribución del estudio científico de las cavidades kársticas al conocimiento geológico, 65-76. Patronato de la Cueva de Nerja. Instituto de Investigación. Carrasco F.; Andreo B.; Benavente J. \& Vadillo I., 
1995 - Chemistry of the water in the Nerja Cave system (Andalusia, Spain). Cave and karst science, 21 (2): 27-32.

Emblanch C.; Zuppi G.M.; Mudry J.; Blavoux B. \& Batiot C., 2003- Carbon-13 of TDIC to quantify the role of the unsaturated zone of karst areas. The example of the Vaucluse karst systems (Southeastern France). Journal of Hydrology, 279: 262-274.

Hoyos Gómez M., Soler Javaloyes V., Cañaveras Jiménez J.C., Sánchez Moral S. \& Sanz Rubio E., 1996- Memoria final sobre las características geológico-kársticas y microambientales de la Cueva de Tito Bustillo, Ribadesella. Informe inédito. Consejería de Cultura del Principado de Asturias. 90 pp.

Jiménez Sánchez M., Anadón Ruiz S., Canto Toimil N., Meléndez Asensio M. \& González Pérez N., 2002a Caracterización hidroquímico-ambiental de la Cueva de Tito Bustillo (Ribadesella, Asturias). In: Carrasco, F., Durán, J. J. \& Andreo, B. (Eds): Karst and Environment, 529-537.

Jiménez-Sánchez M., Anadón-Ruiz S., Farias P., García-Sansegundo J. \& Canto-Toimil N., 2002b, Estudio preliminar de la Geomorfología de la Cueva del Pindal (Ribadedeva, Oriente de Asturias). Geogaceta 31: 47-50.

Jiménez-Sánchez M., Canto Toimil N. \& Anadón Ruiz S., 2004a - Caracterización estratigráfica del relleno sedimentario de la Cueva del Pindal (Ribadedeva, Asturias): implicaciones geomorfológicas.- In: Flor, G. (ed.): Actas de la XI Reunion de AEQUA: 151-158.

Jiménez-Sánchez M., Anadón-Ruiz S., Farias P., García-Sansegundo J. \& Canto Toimil N., -2004b Geomorfología de la cueva de Tito Bustillo y del macizo kárstico de Ardines (Ribadesella, Costa Cantábrica, Norte de España). Boletín del IGME, 2:115: 257-263.

Jiménez-Sánchez M., Bischoff J. L., Stoll H. \& Aranburu A., 2006 - A geochronological approach for cave evolution in the Cantabrian Coast (Pindal Cave, NW Spain). Z. Geomorph. N. F., Suppl. 147: 129-141.

Kaufmann G., 2003 - Modelling unsaturated flow in an evolving karst aquifer. Journal of Hydrology, 276: 5370.

Klimchouk A.B. \& Gudzenko V. V., 1996 - Chernobyl radiocaesium in a karst system, Marble Cave, Crimea. Environmental Geology, 28 (3): 161-166.

Liñán C., Calaforra J. M., Cañaveras J. C., Carrasco F., Fernández Cortés A., Jiménez-Sánchez M., Martín Rosales W., Sánchez Martos F., Soler V. \& Vadillo I., 2004 - Experiencias de monitorización medioambiental en cavidades turísticas. In: Andreo, B. \& Durán, J. J: (Ed.): Investigaciones en sistemas kársticos españoles, Publicaciones del Instituto Geológico y Minero de España. Serie Hidrogeología y Aguas Subterráneas, 12: 385-429. IGME.

Loop C. L., 2004 - Contamination of Cave Waters by NonAqueous Phase Liquids (NPALs). In: Culver D. \& White W. (Eds): Encyclopedia of Caves, 131-137. Elsevier.

Marquínez J., 1989 - Síntesis cartográfica de la Región del Cuera y de los Picos de Europa. -Trabajos de Geología Universidad de Oviedo, 18:137-144.
Martín-Rosales W., López-Chicano M, Rodríguez C.M. \& Pulido-Bosch A., 1995 - Morfología, espeleotemas y climatología de la Gruta de las Maravillas, Aracena (Huelva). Espeleotemas, 5:1-12.

Martín-Rosales W., López-Chicano M, Rodríguez C.M. \& Cerón, J.C., 2007 - Efectos de las medidas de protección ambiental en la Gruta de las Maravillas (Aracena, Huelva). In: Durán, J. J., Robledo, P. A. \& Vázquez J. (\&.): Cuevas Turísticas: aportación al Desarrollo Sostenible. Publicaciones del IGME, Serie Hidrogeología y Agua Subterránea, 24: 169-180, IGME.

Martinez San Miguel E., 1990 - Prevención de inundaciones en la Cueva de Tito Bustillo. Unpublished report. University of Oviedo. 116 pp.

Mudry J., Coxon C., Kilroy G., Kapelj S., Surbeck H \& Vadillo I., 2003 - Specific Vulnerability. Contaminants in carbonatekarst groundwater (inorganic contaminants). Vulnerability and risk mapping for the protection of carbonate aquifers. Action COST 620: 36-43).

Musgrove M. \& Banner J.L., 2004 - Controls on the spatial and temporal variability of vadose dripwater geochemistry: Edwards Aquifer, Central Texas. Geochimica et Cosmochimica Acta, 68 (5): 1007-1020.

Obeso Amado R., Rodríguez Calvo G., Santa Eugenia J. \& Menéndez Rato J., 1996 - La Cueva del Pindal. Unpublished report. Asturias Government. 65 pp.

Otal M. A. \& Buergo, M. A., 1991 - Estudio de la contaminación de rio San Miguel (Ribadesella, Asturias). Unpublished report. Asturias Government, $52 \mathrm{pp}$.

Pulido-Bosch A., Martín-Rosales W., López-Chicano M. \& Vallejos A., 1997 - Human impacts in a touristic cave (Aracena, Spain). Environmental Geology, 31 (3/4): 142-149.

Selker J.S., Keller C.K \& McCord J.T, 1999 - Vadose Zone Processes. Lewis Publishers, $351 \mathrm{pp}$.

Stephens D.B., 1995 - Vadose Zone Hydrology. CRC Press Inc., 370 pp.

Stoll H., Jiménez-Sánchez M., Auer T., Martos de la Torre E., 2007 - Temporal variation in dripwater chemistry in the Cueva del Pindal (Asturias, NW of Spain). In: Durán, J. J., Robledo, P. A. \& Vázquez J. (Eds.): Cuevas Turisticas: aportación al Desarrollo Sostenible. Publicaciones del IGME, Serie Hidrogeología y Agua Subterránea, 24: 191-198, IGME.

Thorn, R.H. \& Coxon, C. E., 1992 - Hydrogeological aspects of bacterial contamination of some western Ireland karstic limestone aquifers. Environmental Geology, 20 (1): 65-72.

Vadillo I.; Andreo B. \& Carrasco, F., 2005 - Groundwater contamination by landfill leachates in a karstic aquifer. Water, Air and Soil Pollution, 165 (1-4): 143-169.

Vesper, D. J., 2004 - Contamination of Cave Waters by Heavy Metals. In: Culver, D. \& White, W. (Eds.): Encyclopedia of Caves. Elsevier: 127-131.

Worthington S.R.H.; Davies G.J. \& Ford D.C., 2000 Matrix, fracture and channel components of storage and flow in a Paleozoic limestone aquifer. In: Sasowsky, I.D. \& Wicks, C.M. (Eds.), Groundwater Flow and Contaminant Transport in Carbonate Aquifers, 113-128. 